\title{
New record of the snake Drymobius chloroticus (Cope, 1886) (Squamata: Colubridae) from Hidalgo, Mexico
}

\author{
Luis Manuel Badillo-Saldaña, Christian Berriozabal-Islas and Aurelio Ramírez-Bautista* \\ Centro de Investigaciones Biológicas (CIB), Universidad Autónoma del Estado de Hidalgo, A.P. 1-69 plaza Juárez Pachuca, Hidalgo, México. \\ * Corresponding author. E-mail: ramibautistaa@gmail.com
}

\begin{abstract}
We report the first record of the snake Drymobius chloroticus (Cope 1886) from Hidalgo State, Mexico. This new record is based on a single juvenile male specimen collected in the municipality of Tepehuacán of Guerrero, Hidalgo. This report fills a gap between the closest localities airline $490.1 \mathrm{~km}^{2} \mathrm{ca}$. NW in Los Tuxtlas, Veracruz, and airline $42.7 \mathrm{ca}$. $\mathrm{km}{ }^{2} \mathrm{SE}$ in the vicinity Xilitla, San Luis Potosí, Mexico.
\end{abstract}

Stuart $(1932,1933)$ recognized four species in the colubrid genus Drymobius, placed by Wilson (1970) into three groups on the basis of color pattern: the margaritiferus group (D. margaritiferus), the rhombifer group (D. rhombifer), and the chloroticus group (D. chloroticus and D. melanotropis). Drymobius chloroticus ranges from Central America to central Mexico (Villa et al. 1988), reaching as far north as Xilitla, San Luis Potosí. The range to extend southeastward to Los Tuxtlas, Veracruz (Figure 1), and to Oaxaca and Chiapas states on the Pacific slopes (Smith and Taylor 1966; Wilson 1970; PerézHigareda et al. 2007). Like all members of the genus, $D$. chloroticus is a medium-sized diurnal snake, found near streams and lakes in areas with abundant vegetation. This species is distributed widely across humid tropical environments in Mexico and Guatemala (Wilson 1970; Wilson and Johnson 2010), and given its occurrence in the adjacent states of San Luis Potosí and Veracruz, it might be expected to occur within Hidalgo as well. However, no documented observations of this species within Hidalgo have yet been published.

During routine field work on 5 October 2011 at 14:30 h, we found a young male (CIB-4187) of D. chloroticus (Figure 2 ) in a cloud forest habitat located in the municipality of Tepehuacán of Guerrero $\left(20^{\circ} 00^{\prime} 02.259^{\prime \prime} \mathrm{N}\right.$; $98^{\circ} 00^{\prime} 00.862^{\prime \prime}$ W, 1480 m), Hidalgo, Mexico. The specimen was collected

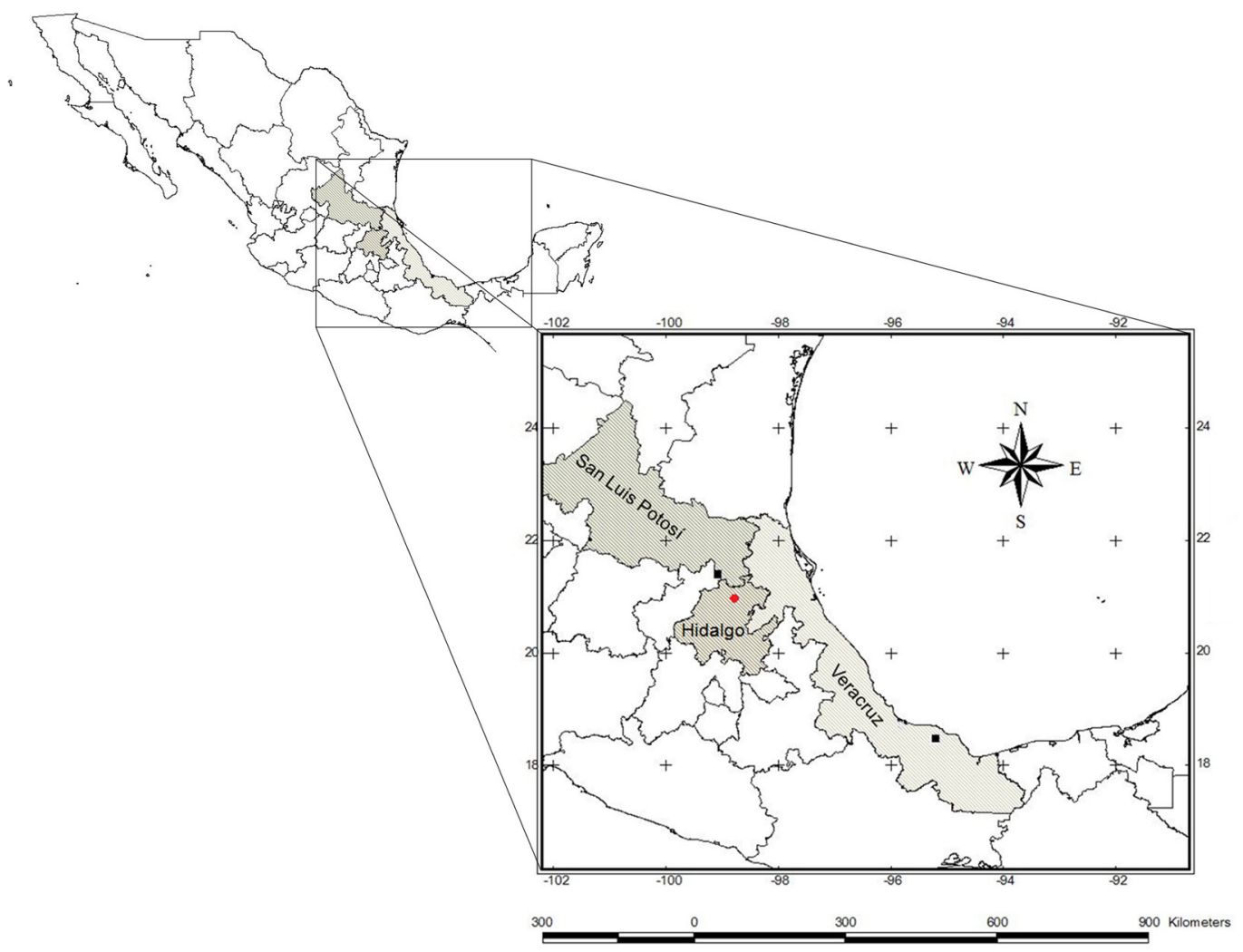

FIGURE 1. Distribution of Drymobius chloroticus in eastern Mexico. Black squares show closest previous records, in Los Tuxtlas, Veracruz, and Xilitla, San Luis Potosí, and the red circle shows the new record in Tepehuacán of Guerrero, Hidalgo, Mexico. 
under approved scientific permit from SEMARNAT (\# SGPA/DGVS/02726/10). The specimen has a SVL of $272.9 \mathrm{~mm}$, and a total length (TL) of $408.3 \mathrm{~mm}$. The main morphological characteristics of the snake include 2 internasal scales, 2 prefrontals, 1 frontal, 1-1 supraoculars, 1-1 parietals, 1-1 loreals, 1-1 preoculars, 2-2 postoculars, 1-1 anterior temporals, and 1-1 posterior temporals (Cope 1886). The dorsal scales are 17-17-15 in arrangement; the ventrals are 153, and the subcaudals 118 . This snake has a long and slender body, with a tail about $33 \%$ of the TL. The dorsal color pattern in yellow-brown with 23 dark patches on the vertebral and lateral regions of the body, the ventral surface is cream in color, as has been described in young D. chloroticus from other populations (Wilson 1970). This pattern has been observed in adult specimens from San Luís Potosí and Oaxaca (Lemos-Espinal and Dixon 2013).

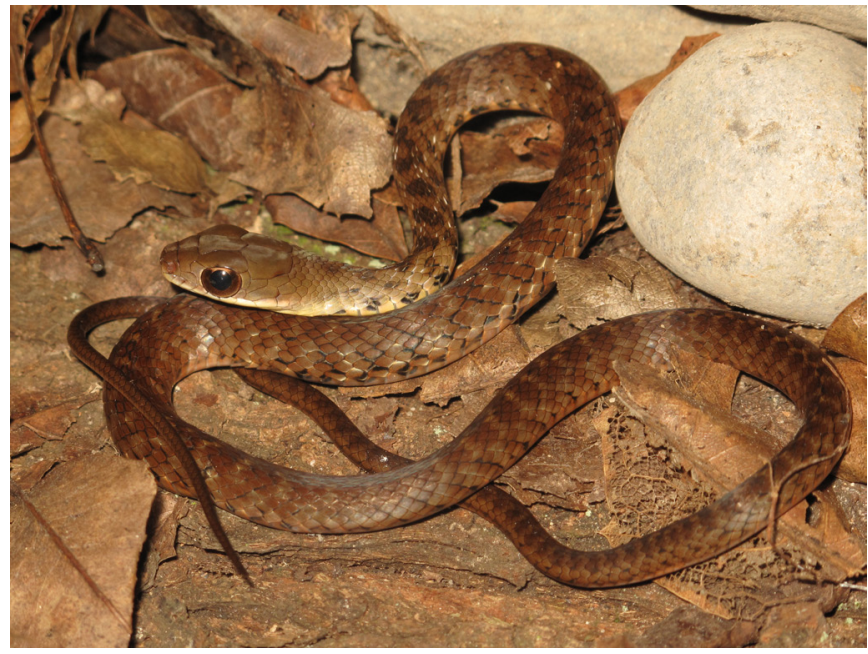

FIGURE 2. Drymobius chloroticus (subadult male) from the Municipality of Tepehuacán of Guerrero, Hidalgo, Mexico. Photo by Christian Berriozabal Islas.

Our record of $D$. chloroticus fills a significant gap between the closest localities ca. $490.1 \mathrm{~km}^{2} \mathrm{NW}$ Los Tuxtlas, Veracruz and ca. $42.7 \mathrm{~km}^{2}$ SE Xilitla, San Luis Potosí, Mexico (Figure 1). The snake was collected on leaf litter in cloud forest (Figure 3A). Known prey items for this species elsewhere in its range consist of amphibians and lizards (Wilson, 1970; Pérez- Higareda et al., 2007; LemosEspinal and Dixon, 2013). This species is sympatric with the lizards Anolis naufragus, A. petersii, and A. lemurinus, and with the amphibians Craugastor loki and C. rhodopis, any of which could be potential prey for this snake. Nevertheless, this snake is apparently very rare in Hidalgo, as we have encountered only one specimen (Figure 2) across a 10-year period of extensive survey work in the state.

This first record of $D$. chloroticus represents an increase in the species diversity of snakes for Hidalgo (RamírezBautista et al. 2010; Berriozabal-Islas et al. 2012), with 81 species now confirmed. The record of this species and the serpent Chersodromus rubriventris (Ramírez-Bautista et al., 2013) found in Tepehuacán of Guerrero, Hidalgo are important for conservation of cloud forest (Figure 3B), because in this vegetation type converge species of Neartic and Neotropical affinity (Challenger and Soberon 2008; Johnson et al. 2010). At the present time, D. chloroticus is not considered within the Mexican normativity for their protection, while for the IUCN Red List is considered as under minor concern, however, the habitat of this species is strongly threatened by a variety of human activities, such as cattle ranching and other agricultural activities in the habitat in which they live (Challenger 1998). The state of Hidalgo still retains large tracts of cloud forest, considered priorities for conservation (Rzedowski 1978; CONABIO 2010), and it is necessary to create multidisciplinary strategies that promote good management of this ecosystem (Berker 2003).
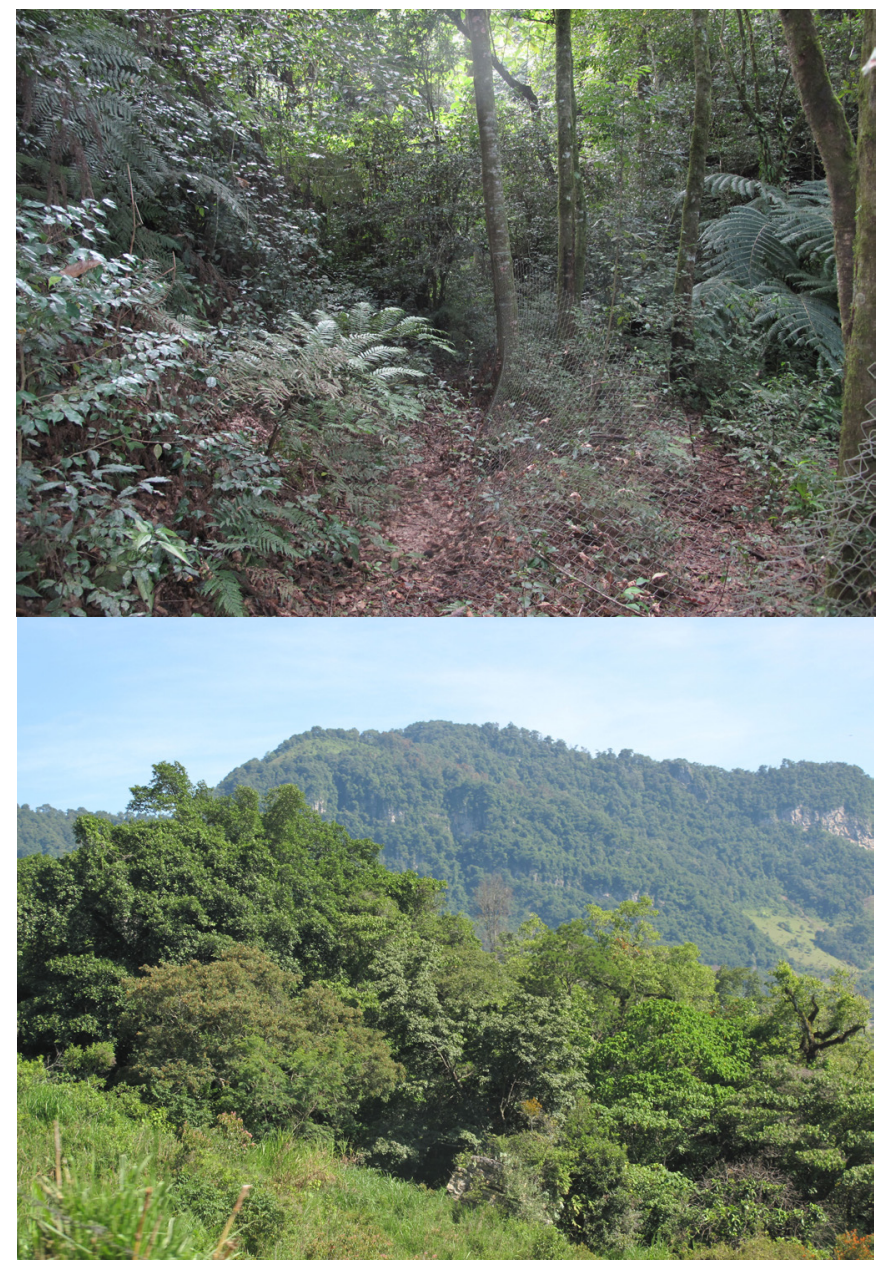

FIGURE 3. (A) Landscape of cloud forest in the Municipality of Tepehuacán of Guerrero, Hidalgo. (B) Cloud forest habitat where D. chloroticus was found. Photos by Luis Manuel Badillo Saldaña

ACKnowledgments: We thank J. Tomás-Villegas, I. Magno-Benítez, D. Lara-Tufiño, R. Cruz-Elizalde, U. Hernández-Salinas and D. JuarezEscamilla for their help in the field, and B. Stephenson for his comments on this manuscript. This study was supported by the projects CONABIO FB1580/JM001/12, and FOMIX 2012/1919908 “Diversidad Biológica del Estado de Hidalgo.

\section{Literature Cited}

Berriozabal-Islas, C., A. Ramírez-Bautista, L.M. Badillo-Saldaña and R. Cruz-Elizalde. 2012. New records of the snake Leptophis diplotropis (Günther, 1872) (Squamata: Colubridae) from Hidalgo State, México. Check List 8(6): 1370-1372.

Berkes, F. 2003. Rethinking community-based conservation. Conservation Biology 18 (3): 621-630.

Challenger, A. 1998. Utilización y conservación de los ecosistemas terrestres de México, pasado, presente y futuro. México DF.: Comisión Nacional para el Conocimiento y Uso de la Biodiversidad: Instituto de Biología, Universidad Nacional Autónoma de México. 847 pp.

Challenger, A. and J. Soberón. 2008. Los ecosistemas terrestres; pp. 87-108, in: J. Soberón, G. Halffter and J. Llorente-Bousquets (ed.). Capital Natural de México, Conocimiento Actual de la Biodiversidad. Comisión Nacional para el Conocimiento y Uso de la Biodiversidad. México, D.F. 
CONABIO. 2010. El bosque mesófilo de montaña en México: Amenazas y oportunidades para su conservación y manejo sostenible. México DF. Comisión Nacional para el Conocimiento y Uso de la Biodiversidad. $197 \mathrm{pp}$.

Cope, E.D. 1886. Thirteenth contribution to the herpetology of tropical America. Proceedings of the American Philosophical Society 23: 271287

Johnson, J.D., V. Mata-Silva and A. Ramírez-Bautista. 2010. Geographic distribution and conservation of the herpetofauna of southeastern México; pp. 322-369, in: L.D. Wilson, J.H. Townsend and J. D. Johnson (ed.). Conservation of Mesoamericans amphibian and reptile. China: Eagle Mountain.

Lemos-Espinal, J.A. and J.R. Dixon. 2013. Amphibians and reptiles of San Luis Potosí. China: Eagle Mountain Publishing, L.C. 300 pp.

Pérez-Higareda, G., M.A. López-Luna and H.M. Smith. 2007. Serpientes de la región de Los Tuxtla, Veracruz, México, Guía de identificación ilustrada. México D.F.: Universidad Nacional Autónoma de México. $189 \mathrm{pp}$.

Ramírez-Bautista, A., U. Hernández-Salinas, F. Mendoza-Quijano, R. CruzElizalde, V.D. Vite-Silva, B.P. Stephenson and A. Leyte-Manrique. 2010 Lista anotada de los anfibios y reptiles del estado de Hidalgo, México. México D. F.: Universidad Autónoma del Estado de Hidalgo, Comisión Nacional para el Conocimiento y Uso de la Biodiversidad. 104 pp.

Ramírez-Bautista, A., C. Berriozabal-Islas, R. Cruz-Elizalde, U. HernándezSalinas and L.M. Badillo-Saldaña. 2013. Rediscovery of the snake Chersodromus rubriventris (Squamata: Colubridae) in could forest of the Sierra Madre Oriental, México. Western North American Naturalist 73(3): 392-398.
Rzedowski, J. 1978. Vegetación de México. México D. F.: Editorial Limusa. $432 \mathrm{pp}$.

Smith, H.M. and E.H. Taylor. 1966. Herpetology of México. Annotated checklist and keys to the amphibians and reptiles. A Reprint of Bulletins 187, 194 and 199 of the United States Natural Museum with a list of subsequent taxonomic innovations. Ashton: Eric Lundberg. 610 pp.

Stuart, L.C. 1932. Studies on Neotropical Colubrinae I: The taxonomic status of the genus Drymobius Fitzinger. Occasional Papers of the Museum of Zoology, University of Michigan 236: 1-16.

Stuart, L.C. 1933. Studies on Neotropical Colubrinae III. The taxonomic status of certain Neotropical racers. Copeia 1: 9-10.

Villa, J., L.D. Wilson and J.D. Johnson. 1988. Middle American Herpetology A Bibliographic Checklist. Columbia: University of Missouri press. 131 pp.

Wilson, L.D. 1970. A review of the Chloroticus group of the Colubrid Snakes Genus Drymobius, with Notes on a Twin-Striped Form of $D$. chloroticus (Cope) from Southern Mexico. Journal of Herpetology 4: 155-163.

Wilson, L.D. and J.D. Johnson. 2010. Distributional patterns of the herpetofauna of Mesoamerica, a biodiversity hotspot; pp. 31-235, in: L.D. Wilson, J.H. Townsend and J.D. Johnson (ed.). Conservation of Mesoamerican amphibians and reptiles. China: Eagle Mountain.

RECEIVED: April 2013

ACCEPTED: December 2013

Published online: February 2014

EDITORIAL RESPONSIBILITY: Pedro H. Bernardo 